\title{
Agroforestry - The Most Resilient Farming System for the Hilly Northwest of Vietnam
}

\author{
Lua Thi Hoang (Corresponding author) \\ World Agroforestry Centre Vietnam, 13th Floor, HCMCC Tower, 249A Thuy Khue street, Tay Ho \\ District, Hanoi Vietnam, Tel: +84 43783 4645, E-mail: luahoang16@gmail.com \\ James M. Roshetko \\ World Agroforestry Centre, Southeast Asia Regional Program, PO Box 161, Bogor 16001, \\ Indonesia, Tel: +62 251 8625415, E-mail: j.roshetko@cgiar.org \\ Thuong Pham Huu \\ World Agroforestry Centre Vietnam, 13th Floor, HCMCC Tower, 249A Thuy Khue street, Ho \\ District, Hanoi Vietnam, Tel: +84 43783 4645, E-mail: p.thuong@cgiar.org
}

Tim Pagella

School of Environment, Natural Resources and Geography, Bangor University, Bangor LL57 2UW, United Kingdom, Tel: +44 1248 382286, E-mail: t.pagella@bangor.ac.uk

Phuong Nguyen Mai

World Agroforestry Centre Vietnam, 13th Floor, HCMCC Tower, 249A Thuy Khue street, Ho District, Hanoi Vietnam, Tel: +84 43783 4645, E-mail: p.thuong@cgiar.org

(Received: May 9, 2017; Reviewed: May 12, 2017; Accepted: June 1, 2017)

\section{DOI: http://dx.doi.org/10.20956/ijas.v5i1.1166}

\begin{abstract}
Over 94\% of the land of northwestern Vietnam is classified as sloping. Population growth has exerted pressure on local natural resources, with agricultural expansion on steep slopes resulting in forest degradation, landscape fragmentation and severe environmental consequences. Efforts to restore forest ecosystems have been made by the government, however, as the livelihoods of $80 \%$ of the population depend on agriculture, the reconversion of land to forest has proven to be an inappropriate solution. Agroforestry offers a potentially sustainable land-use solution, which could re-establish forests, restore ecosystem services, and stabilize local livelihoods. In this paper, we assess the potential of agroforestry development in the region based on the results of two interrelated surveys conducted in 21 representative villages in six districts of three northwestern provinces: 1) a farming system diagnosis implemented in 17 representative villages; and 2) an agroforestry adoption survey with 210 households practising agroforestry in 14 villages. The analysis was strengthened by four years' experience in implementing an extensive agroforestry project in the region. The studies focussed on assessing key benefits and constraints of existing farming systems, including agroforestry practices, adopted by farmers and identifying the potential for agroforestry development in the region. The results showed that the dominant farming system in the north-western provinces was monoculture of staple crops on slopes, which provided relatively low economic returns. Soil erosion, land degradation, and water shortages resultant from intensive farming practices were the most significant environmental issues in the area. Tree-based farming systems were rare and mostly a result of spontaneous adoption by farmers. Given the mountainous landscape and the need for soil stabilization, agroforestry was seen by farmers as a viable approach. Improving the existing and adopting new, integrated agroforestry systems were identified as viable ways toward sustainable livelihoods in Northwestern Vietnam.
\end{abstract}

Keywords: Agroforestry development; farming systems; north-western Vietnam; livelihoods' improvement; agroforestry adoptions 


\section{Introduction}

Over $94 \%$ of the land of northwestern Vietnam is classified as sloping, of which $87 \%$ has slope above $25^{\circ}$ (Khanh, 2012). The region features six provinces with an area of 5.64 million ha and a total population of 3.5 million made up of 30 different ethnic groups with distinct languages, traditions and farming practices. An estimated $80 \%$ of the population depends heavily on agriculture for their livelihoods (IPCN Vietnam, 2016). Population growth, partly as a result of a government resettlement policy 19611998, exerts pressure on available natural resources. Deforestation and expansion of agriculture onto steep slopes using predominantly monocropping practices in the last few decades has resulted in forest loss, degradation of agro-ecosystems and landscape fragmentation that threatens environmental sustainability and food security (Hoang et al. 2010).

Efforts to restore forest ecosystems have been made by the Government of Vietnam through the Five Million Hectares Reforestation Program. As a result of this reforestation effort of the last few decades, forest area has increased from 7.8 million ha in 1981 to 13.1 million ha in 2008 (VNFOREST), however, the quality of forest remains poor as the underlying drivers of forest loss are still present (Stibig et al. 2007; Government of Vietnam 2007; CEM Vietnam). The primary reason for forest conversion is that local livelihoods still depend on small-scale agriculture; converting locally-valuable agricultural land to forest is not viable (Chaudhury, 2009). Indeed, farmers in the region have continued to clear forests (Long, 2009).

Along with deforestation, the frequency and intensity of extreme weather events (floods, landslides, frosts, droughts) have increased. The damages resulting from these extreme events increased by a factor of 10 from 2001-2005 to 2006-2010 (DONRE Son La 2014).

Globally, there has been a steadily increasing interest in the development of agroforestry systems to enhance resilience. FAO has also recently issued a guide for policy-makers, Advancing Agroforestry on the Policy Agenda, which aims to promote agroforestry in national policy frameworks and boost its impact (FAO, 2013). Agroforestry has been used widely to address soil erosion and rehabilitate soil fertility (Nair 1993; Pattanayak and Mercer 1996; Young 2002; Hasan and Ashraful 2006; Jama et al. 2006; Blanco-Canqui and Lal 2008; Rachel et al. 2012). Additionally, well-designed agroforestry interventions provide permanent soil cover, improve soil and water use-efficiency, restore tree cover and increase carbon stocks (Rao et al. 2007; Roshetko et al. 2007; Brenda, 2010; Charles et al. 2013; Roshetko et al. 2013). Through soil fertility and, thus, productivity improve-ment, agroforestry contributes to food and nutritional security (Dawson et al. 2013; Jamnadass et al. 2013). Agroforestry is considered to be a best alternative for climate-smart agriculture (Kaczan et al. 2013); and provide an opportunity to combine the twin objectives of adaptation and mitigation (Verchot et al. 2007; Murthy et al. 2013; Mbow et al. 2014; Lasco et al. 2014). 
A shift to integrated agroforestry systems on smallholdings offers a more sustainable land-use solution. This would stabilize local smallholders' livelihoods whilst gradually restoring lost regulating ecosystem services in the area. Within this region, the primary benefits of agroforestry would be to address chronic erosion (particularly on slopes above $25^{\circ}$ ), which presents a significant long-term threat to local livelihoods' systems. Recent trends away from swidden agriculture towards cash cropping have reduced the ecological complexity of local agro-ecosystems (Pham et al. 2015). The introduction of more complex agroforestry systems can increase the biodiversity of these systems and broaden the range of products produced; both of which will build resilience in local farming systems. The initial results from agroforestry trials initiated in 2012 by the Agroforestry for Livelihoods of Smallholder Farmers in north-western Vietnam (AFLI) project show that agroforestry systems with grass strips planted on contours significantly reduce soil erosion (by up to $74 \%$ during the 2016 rainy season) (La et al. 2016). Data on the economic returns are not yet available as the associated trees have not reached productive ages.

The paper presents a combined result of two interrelated surveys: 1) a farming system diagnosis (FSD) that focused on identifying the dominant farming systems in the region, assessing the strengths, weaknesses and resilience levels of each system; and 2) an agroforestry adoption survey centring specifically on the agroforestry practices adopted by farmers in the region and exploring the potential for their wider adoption. The studies sought to answer the following questions.

i) What are the dominant farming systems in the study sites; what are the strength and weakness of each system; and to what extent are they resilient within the smallholder livelihoods' systems?

ii) What are the agroforestry practices adopted by farmers and what are the reasons for their adoption?

iii) Is there evidence that farming systems that integrate agroforestry practices are more resilient than systems that do not?

iv) What is the potential for expanding locally successful agroforestry systems?

\section{Methodology}

\subsection{Study location}

The studies were conducted in 21 villages located between 300 and 1250 metres above sea level (masl) in 12 communes of six districts in the three northwestern provinces of Yen Bai, Son La and Dien Bien (Table 1). These villages were purposively selected as they were part of the AFLI project. The villages were grouped into three elevation ranges with different predominant farming systems related to the elevation and local ethnic groups. The FSD was conducted in 17 of the total 21 villages and the agroforestry adoption survey in 14 villages (Figure 1 and Table 1 in the results section).

\subsection{Methods and data}

\section{Farming systems diagnosis}

The assessment methods included agroecological mapping, focus-group discussions (FGD), and structured interviews. 


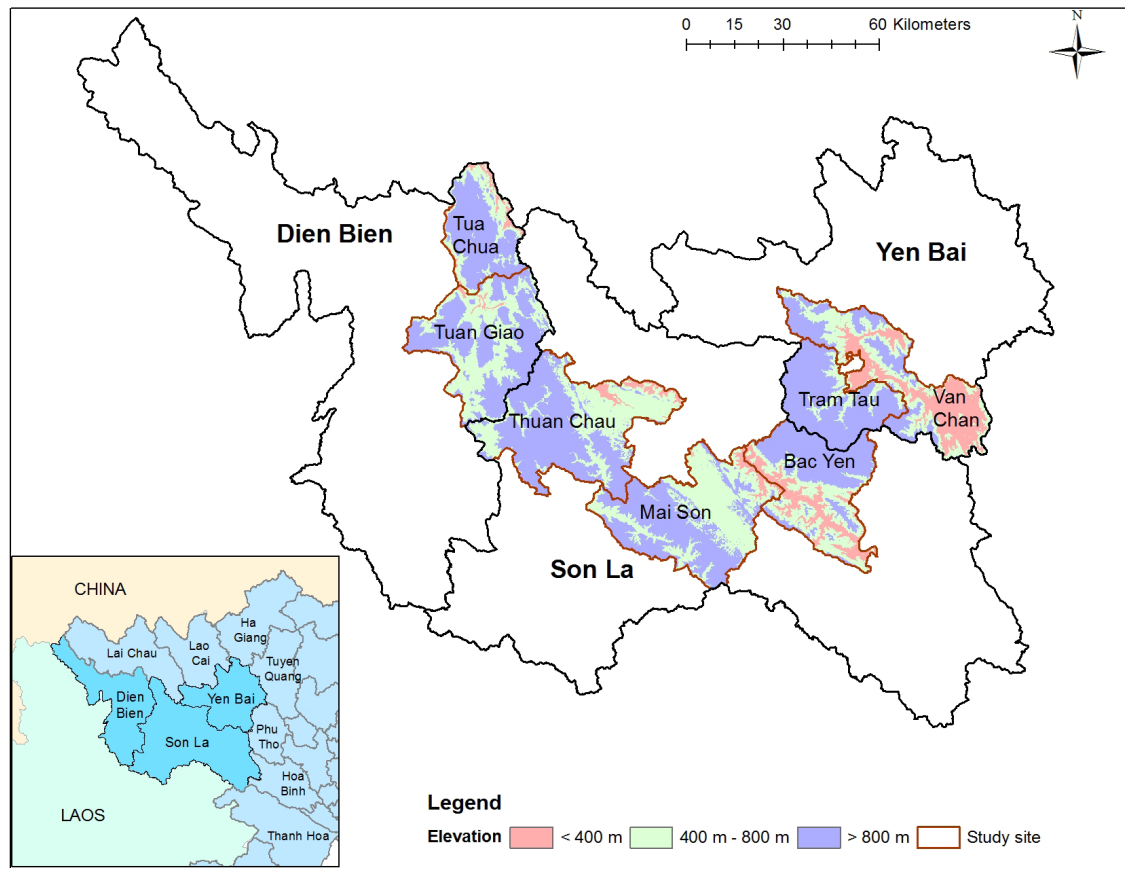

Figure 1. Map of the study location

Agro-ecological maps were created through village transect walks with 10 -to- 15 residents per village. Dominant land-use systems associated with different elevation intervals and degrees of slope were identified, including crop varieties, cropping systems and patterns (monocropping or crop association), and agroforestry systems. Three biophysical indicators were registered: 1) soil type; 2) erosion status; and 3) water resources.

Focus-group discussions encompassed 1520 randomly selected farmers per village. In total, two hundred and seventy-eight (278) farmers participated in the FGD. The discussions consisted of semi-structured interviews on the village's farming systems, including the dominant farming systems (to complement the result of the transect walk), land-use history, farming calendar and a Strengths, Weaknesses, Opportunities and Threats (SWOT) analysis of each system. The purpose was also to generate information for a rapid economic and resilience assessment of the dominant cropping systems. Farmers' landholdings in the study areas were fragmented, with each parcel varying by size, slope, location, accessibility, and investment levels. To balance the varied conditions across farms and parcels, the group discussions were used to calculate average input costs, incomes and profits of the dominant systems in each surveyed village. The discussions helped the research team better understand the nature of the challenges faced by farmers in their farming practices, provided data on indigenous methods for preventing erosion and indicated the levels of farmers' awareness of agroforestry.

\section{Rapid economic assessment of dominant} cropping systems explored the profitability of the farming systems per hectare per year:

Total profit: $\operatorname{Pr}=\operatorname{In}-$ Exp

Where, $\operatorname{Pr}=$ profit $(\$ /$ ha $/$ year $)$;

In $=$ total income (turnover) ( $\$ /$ ha/year); and $\operatorname{Exp}=$ total cost for all inputs: labour time, 
seeds/seedlings, fertilizers, pesticides, herbicides, tools etc. ( $\$ /$ ha/year).

The resulting economic effectiveness of the dominant farming systems in each village was calculated as the average value of all inputs and outputs in the last three harvesting seasons, provided by farmers in each surveyed village during the FGD. The cost of labour was set at USD 5 per day, an average hired labour price in the agricultural sector in the region.

Resilience assessment: in the study, a resilient farming system was defined as a farming system that sustainably increases productivity and is able to adapt to changes in climatic conditions while reducing negative impacts on the environment. Regarding environmental impacts, our study emphasized control of soil erosion in the cropping systems, a common problem in the study area.

Structured interviews were conducted with 45 farmer co-operators who participated in project trials. The main purpose was to collect base information about households and their agricultural production, including farming practices, main livelihoods' sources and tree-planting practices (questionnaire is provided in annex 1).

\section{Agroforestry adoption survey}

The main methods used were semi-structured interviews with 210 households in 14 villages who practised agroforestry and observations of the households' land during field visits. The information collected included i) basic information of the household, including their farming practices; ii) types of agroforestry systems farmers practised, with system components; criteria for species selection; area and year of establishment; iii) the reasons farmers adopted agroforestry practices; and iv) from where did they learn about agroforestry.

The interviews explored the spatial arrangements, species' selection criteria and farmers' evaluations of the benefits of the systems. For the purposes of this study, agroforestry was defined as a "collective name for land-use systems and practices where woody perennials are deliberately integrated with crops and/or animals on the same land management unit. The integration can be either in spatially mixed or temporal sequence. There are normally both ecological and economic interactions between the woody and non-woody components in agroforestry' (ICRAF 1982).

\section{Statistical method}

The data collected in this study were analysed using descriptive statistics to calculate the frequency distribution and percentage of variables. The SPSS, version 16 (2007), program was used to generate the analysis.

\section{Result}

\subsection{General findings and issues}

The transect maps of 17 villages showed similar characteristics. For example, the transect map of Nhop village (Figure 2) shows typical land uses associated with certain topographical, soil, water and erosion features.

The highest point of village transect maps was usually rocky mountains with natural forests, descending along steepto-moderate slopes with mono-cultivation of staple crops through comparatively flat areas with homegardens to paddy rice on the 


\begin{tabular}{|c|c|c|c|c|}
\hline $\begin{array}{l}\text { Land } \\
\text { use }\end{array}$ & Paddy field & Homegarden & $\begin{array}{l}\text { Cultivated area } \\
\text { (upland) crops) }\end{array}$ & $\begin{array}{l}\text { Plantation and } \\
\text { regenerated forest }\end{array}$ \\
\hline Slope & Flat & Flat & $\begin{array}{l}\text { Moderate steep }(5- \\
\left.15^{\circ}\right)\end{array}$ & $\begin{array}{l}\text { Steep } \\
\left(>15^{\circ}\right)\end{array}$ \\
\hline Species & Paddy rice & $\begin{array}{l}\text { Canarium, coffee, fruit species } \\
\text { around homegarden }\end{array}$ & Cassava & $\begin{array}{l}\text { Bamboo, Acacia } \\
\text { auriculiformis, } \\
\text { regenerated shrubs }\end{array}$ \\
\hline $\begin{array}{l}\text { Soil } \\
\text { status }\end{array}$ & Rich soil & $\begin{array}{l}\text { Rich soil, high content of } \\
\text { humus. }\end{array}$ & Red soil, no gravel & $\begin{array}{l}\text { Rich soil mixed with } \\
\text { little gravel; black } \\
\text { soil, red layer } \\
\text { beneath. }\end{array}$ \\
\hline Soil layer & $50-60 \mathrm{~cm}$ & $50-60 \mathrm{~cm}$ & $30-40 \mathrm{~cm}$ & $20-30 \mathrm{~cm}$ \\
\hline Problems & $\begin{array}{l}\text { Limited area for } \\
\text { paddy }\end{array}$ & $\begin{array}{l}\text { Lack of an effective } \\
\text { homegarden design }\end{array}$ & $\begin{array}{l}\text { Water scarcity, high } \\
\text { soil erosion and } \\
\text { runoff }\end{array}$ & Forest quality low \\
\hline $\begin{array}{l}\text { Farmers' } \\
\text { potential } \\
\text { solutions }\end{array}$ & $\begin{array}{l}\text { Build irrigation } \\
\text { system; add } \\
\text { manure }\end{array}$ & $\begin{array}{l}\text { Intercropping timber or fruit } \\
\text { tree species and coffee }\end{array}$ & $\begin{array}{l}\text { Tree-based farming } \\
\text { system }\end{array}$ & $\begin{array}{l}\text { Forest regeneration } \\
\text { and enrichment with } \\
\text { hybrid acacia }\end{array}$ \\
\hline
\end{tabular}

Figure 2. Sample transect from a typical upland village, Nhop, in Thuan Chau district (1150 m)

valley floor. Potential solutions for common problems found in each elevation category were provided by farmers (see example in the bottom row of Figure 2). Key landscape issues are discussed below.

Natural forest cover: Initial indicators suggested that at all elevations natural forest had been substantially degraded, greatly reduced in size and suffered significant fragmentation. Farmers reported that timber for housing was no longer available and non-timber forest products were very limited. The contribution of natural forests to local livelihoods was limited to firewood collection and a few medicinal plants and mushrooms. Farmers wanted to plant these areas with fast-growing timber to provide building material.

Water scarcity: Nearly all agricultural production, especially on slopes, was rainfed. Water was increasingly scarce in nearly all villages of the surveyed area. This affected the productivity of crops in several ways. First, owing to water shortages, farmers could plant only one (autumn) crop a year and the fields were left without groundcover for months, with exposure to early rains resulting in accelerated erosion. This land degradation led to further reduction of soil water-holding capacity thereby accentuating the water deficiency.

Soil erosion: As observed, soil erosion was a significant problem in the region. Farmers acknowledged that on sloping land 
the soil layer was becoming thinner over the years owing to intensive and continuous monocultural cultivation. This had resulted in significant loss of soil fertility and declining yields.

Farming systems: Systems were characterized by fragmented fields on steep slopes that were remote and difficult to access. Mono-cropping of staple crops, especially maize or cassava, on steep slopes was common and intensive at all altitudes (Annex 2, Table A2.1), although above 800 masl these problems were less severe because the agricultural systems were mostly for subsistence.

Resilience: The common mono-cropping systems with staple crops, especially maize, were characterized by low economic returns; high levels of vulnerability to pests, diseases, and extreme weather events; market price fluctuations; and exposure of the soil to erosion and degradation.

Agroforestry: Homegardens with mixed systems were very common across the study area. However, away from the homesteads there was limited evidence of agroforestry systems. The percentage of households practising agroforestry was low, except in Long and Nhop villages where coffee-based systems were common and $\mathrm{Ta}$ Xua village where farmers planted shortrotation crops in shan tea plantations (see Table 1).

The results of individual interviews showed that agriculture was the main income source for over $95 \%$ of respondents, with the main cash crops being maize $(82 \%)$, and paddy rice, coffee or tea $(18 \%)$. Landholdings in the areas averaged $1 \mathrm{ha} /$ household. The most important factors for the farmers in deciding which trees and/or crops to plant or which farming system to apply were the products' market availability, land and capital resources. According to farmers, the main factors in maintaining good yields were, first, soil erosion (mentioned by $85 \%$ interviewed), followed by water availability $(65 \%)$ and soil fertility (52\%). Only a few farmers mentioned inputs as the main factor for good yields. This clearly indicated that soil erosion and related issues - declining fertility and water availability — were the key problems in the region.

Economic analysis: The profitability of each cropping system identified during the FGD in the 17 study villages is summarized in the last column of Table 2. The column also includes profit data of some agroforestry systems in the study areas, according to farmers' recollections for the previous year. The detailed profit data of all dominant systems in each study village are provided in annex 2 Table A2.2.

\subsection{Farming systems in three agro- ecological zones}

Since cropping patterns and, hence, farming practices varied significantly between elevations, results are reported according to elevation and agro-ecological zone. There were only slight variations within the range of elevations and from one location to another. Table 2 summarizes all dominant farming systems by elevation.

\section{Farming systems below 400 masl}

The dominant farming system at this elevation was monocultural hybrid maize with two harvests per year on sloping land. The 
Table 1. List of study villages including percentage of households, adopted agroforestry

\begin{tabular}{|c|c|c|c|c|c|c|c|c|}
\hline $\begin{array}{l}\text { Altitude } \\
\text { (masl) }\end{array}$ & Province & Commune & Villages & $\begin{array}{l}\text { Ethnic } \\
\text { group }\end{array}$ & $\begin{array}{c}\text { No. of } \\
\text { househ } \\
\text { olds }\end{array}$ & $\begin{array}{l}\text { Village } \\
\text { in FSD }\end{array}$ & $\begin{array}{l}\text { Village in } \\
\text { adoption } \\
\text { survey }\end{array}$ & $\begin{array}{c}\text { Percentage of } \\
\text { households that } \\
\text { adopted agroforestry }\end{array}$ \\
\hline \multirow{3}{*}{$<400$} & \multirow{3}{*}{ Yen Bai } & \multirow{3}{*}{ Son Thinh } & Hong Son & \multirow{3}{*}{ Kinh } & 200 & $\mathrm{X}$ & $\mathrm{X}$ & 4.0 \\
\hline & & & Van Thi 4 & & 117 & $\mathrm{X}$ & $\mathrm{X}$ & 1.7 \\
\hline & & & Thac Hoa & & 107 & & $\mathrm{X}$ & 2.0 \\
\hline \multirow{8}{*}{$\begin{array}{l}400- \\
800\end{array}$} & \multirow{5}{*}{ Son $\mathrm{La}$} & \multirow{2}{*}{$\begin{array}{l}\text { Chieng } \\
\text { Chan }\end{array}$} & Sai Luong & \multirow{3}{*}{ Thai } & 129 & $\mathrm{x}$ & $\mathrm{X}$ & 4.0 \\
\hline & & & $\mathrm{Na}$ Phuong & & 95 & & $\mathrm{X}$ & 7.4 \\
\hline & & \multirow{3}{*}{ Co Noi } & Mon & & 152 & $\mathrm{x}$ & $\mathrm{X}$ & 2.0 \\
\hline & & & Phieng Hy & H'mong & 45 & $\mathrm{x}$ & & - \\
\hline & & & Tan Que & Kinh & 55 & & $\mathrm{X}$ & 9.0 \\
\hline & \multirow{2}{*}{$\begin{array}{l}\text { Dien } \\
\text { Bien }\end{array}$} & \multirow[t]{2}{*}{ Quai Nua } & Chan & \multirow[t]{2}{*}{ Thai } & 48 & $\mathrm{x}$ & & - \\
\hline & & & Cha & & 68 & $\mathrm{x}$ & & - \\
\hline & Yen Bai & Ban Cong & Khao Chu & H'mong & 96 & & $\mathrm{X}$ & 2.0 \\
\hline \multirow{10}{*}{$>800$} & \multirow[t]{3}{*}{ Son La } & $\begin{array}{l}\text { Chieng } \\
\text { Bom }\end{array}$ & Nhop & Thai & 84 & $\mathrm{x}$ & $\mathrm{X}$ & 99.0 \\
\hline & & Co Ma & Co Ma & H'mong & 66 & $\mathrm{x}$ & $\mathrm{X}$ & 6.0 \\
\hline & & Long $\mathrm{He}$ & $\begin{array}{l}\text { Nong Coc } \\
\text { A }\end{array}$ & Kho $\mathrm{Mu}$ & 80 & $\mathrm{x}$ & & - \\
\hline & \multirow{3}{*}{$\begin{array}{l}\text { Dien } \\
\text { Bien }\end{array}$} & \multirow{3}{*}{ Toa Tinh } & Che A & \multirow{3}{*}{ H'mong } & 55 & $\mathrm{x}$ & & - \\
\hline & & & Hua Sa A & & 80 & $\mathrm{x}$ & $\mathrm{X}$ & 5.0 \\
\hline & & & Long & & 110 & $\mathrm{x}$ & $\mathrm{X}$ & 56.4 \\
\hline & $\begin{array}{l}\text { Dien } \\
\text { Bien }\end{array}$ & Ta Phin & Ta Phin & H'mong & 55 & $\mathrm{x}$ & & - \\
\hline & \multirow[t]{2}{*}{ Yen Bai } & \multirow[t]{2}{*}{ Suoi Giang } & Giang B & \multirow[t]{2}{*}{ H'mong } & 79 & $\mathrm{x}$ & & - \\
\hline & & & Pang Cang & & 116 & $\mathrm{x}$ & $\mathrm{X}$ & 3.4 \\
\hline & Yen Bai & Ban Cong & Ta Xua & H'mong & 82 & $\mathrm{x}$ & $X$ & 22.0 \\
\hline
\end{tabular}

[Source: Survey data]

average yield ranged 3-5 t grain/ha/crop. The second most common crop was monocultural, high-yield cassava (Manihot esculenta Craz.), which was cultivated where soil fertility had declined and could no longer support maize. The average yield ranged 18-22 t/ha/crop. In general, cassava cultivation brought low economic returns owing to low and unstable prices (see Table 2). In areas with available irrigation, monocultural rice (Oryza sativa) was planted with two crops a year. The average yield ranged 3-5 t/ha/crop, depending on local conditions. Bush tea (Camellia sinensis) was the leading cash crop. Fast-growing timber species, such as acacia (Acacia mangium, Acacia auriculiformis or acacia hybrid), eucalyptus hybrid (Eucalyptus urophylla x Eucalyptus camaldulensis), Manglietia conifera and Styrax tonkinensis were mostly planted on heavily-degraded soils unsuitable for annual crops.

Agroforestry systems: Most homesteads had homegardens containing a mix of fruit tree species - for example, mango (Mangifera indica L), longan (Dimocarpus longan Lour), pomelo (Citrus grandis (L.) Osbeck) and orange (Citrus sinensis (L.) Osbeck) - combined with timber trees and/or vegetables. The next-most common agroforestry systems were bush tea with timber trees for shade (manglietia, acacia, melia (Melia azedarach), eucalyptus hybrid); fruit trees with annual crops - for 
Table 2. Farming systems in the study villages, by elevation including system profit

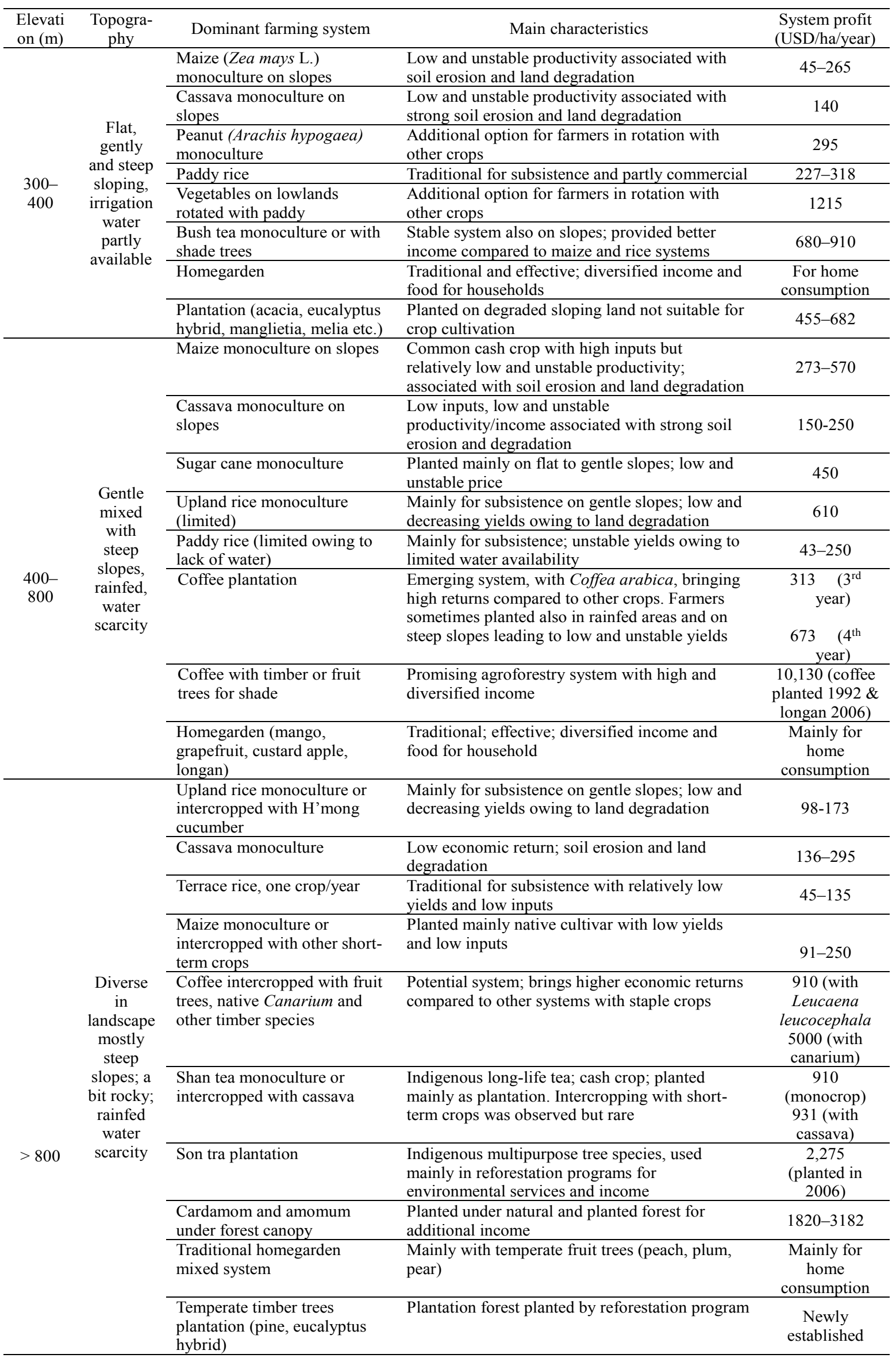


example, longan or orange with maize or ginger (Zingiber officinale Rose) - and; mixed systems (bush tea, banana (Musa $x$ paradisiaca L.), eucalyptus hybrid, acacia, melia, maize) (Table 3). These systems were established mostly on gentle to steep slopes.

Farming systems in intermediate elevations: 400-800 masl

At these altitudes, there were a greater number of fields on higher slope grades, limited water availability and severe soil degradation. Monocultural food crops on sloping land continued to be dominant: maize and cassava were most intensive and paddy rice cultivation restricted because of water scarcity. The average yield of maize per crop was higher (up to $8 \mathrm{t} / \mathrm{ha}$ ) than at elevations below 400 masl, especially in Mai Son district where farmers planted hybrid maize varieties, with high application of fertilizers, for commercial purposes. Upland rice was also planted as monoculture on hillsides in rotation with cassava. Despite low yields (1.2-1.4 t/ha) owing to depletion of soil nutrients, it was maintained as an important subsistence crop.

Perennial cash crops were dominated by bush tea in Yen Bai and coffee (Coffea arabica) in Son La and Dien Bien. Coffee plantations had expanded over the last few years as monoculture or, infrequently, in association with fruit or timber trees. Farmers preferred coffee to other traditional food crops because of its higher economic return. However, only wealthier farmers could afford the investment to establish coffee plantations. Timber tree species - for example, mahogany (Chukrasia tabularis A. Juss) and canarium (Canarium nigrum) - or fruit trees were planted in limited numbers as shade in coffee plantations. Fruit tree species in homegardens - for example, longan, mango, plum and custard apple (Annona squamosa L.) - were grown scattered through the gardens and as shade trees for coffee.

Agroforestry systems: Coffee-based agroforestry systems were the most encountered intercropping system at this elevation. Coffee was intercropped with fruit trees or with timber trees for shade (Table 3). Some systems with fruit trees and annual crops were also observed on a small scale.

\section{High elevations: above 800 masl}

The farming systems at high elevations were less diverse in terms of species than at lower elevations, however, monocultural staple crops (maize, cassava and upland rice) on sloping land continued to be a common practice. The crops grown by the H'mong people were mainly for subsistence. Compared to farmers at lower elevations, H'mong farmers primarily used local varieties of upland rice, maize and cassava with limited inputs, resulting in lower yields. The average maize yield varied 1.5-3 t/ha/year, cassava 10-15 t/ha/ year and upland rice mostly stable at $1 \mathrm{t} / \mathrm{ha}$. Crop yields were said to be declining owing to germplasm degeneration. Some crop species were traditionally intercropped or planted in rotation during the rainy season. Paddy rice was mainly planted on terraces. Common tree species were pine (Pinus sp.), Vernicia montana, manglietia and Fokienia hodginsii. In homegardens, common fruit trees were pear (Pyrus sp.), plum 
(Prunus salicina), peach (Prunus persica), persimmon (Diospyros decandra Lour) and son tra (Docynia indica). Some households planted son tra for income generation with the support of government reforestation projects.

Agroforestry systems: The types of agroforestry systems at this elevation were diverse. The most common systems were coffee with shade trees, shan tea (Camellia sinensis O.
Ktze) with short-term crops and amomum (Amomum sp.) or cardamom (Amomum aromaticum Roxb.) under canopy of natural or planted forest with son tra and pines. The systems differed from region to region, for example, in Son La the most common system was coffee, in Yen Bai shan tea, and in Dien Bien amomum or cardamom under natural or planted forest (Table 3 ).

Table 3: Agroforestry systems at three ranges of elevation in the study sites and corresponding number of households practising the systems

\begin{tabular}{|c|c|c|c|c|}
\hline No. & System components & $\begin{array}{l}\text { Elevation } \\
\text { (masl) }\end{array}$ & $\begin{array}{l}\text { No. of households with } \\
\text { agroforestry systems out } \\
\text { of total number of } \\
\text { households surveyed }\end{array}$ & Location \\
\hline 1 & Longan, maize & \multirow[b]{3}{*}{$\begin{array}{c}\text { Below } \\
400\end{array}$} & $5 / 424$ & \multirow{3}{*}{$\begin{array}{l}\text { Son Thinh } \\
\text { commune, } \\
\text { Van Chan } \\
\text { district, Yen } \\
\text { Bai province }\end{array}$} \\
\hline 2 & Orange and short-term crops, such as maize, ginger & & $3 / 424$ & \\
\hline 3 & $\begin{array}{l}\text { Bush tea with one or several components: maize, } \\
\text { eucalyptus hybrid, acacia, banana, longan, melia }\end{array}$ & & $6 / 424$ & \\
\hline \multirow[t]{2}{*}{4} & Coffee-based systems & \multirow{5}{*}{$400-800$} & & \multirow{5}{*}{$\begin{array}{l}\text { Mai Son } \\
\text { district, Son } \\
\text { La province }\end{array}$} \\
\hline & $\begin{array}{l}\text { Coffee with fruit trees (one fruit tree species or } \\
\text { mix of fruit trees, including longan, mango, } \\
\text { custard apple, plum) } \\
\text { - Coffee with eucalyptus hybrid or Chukrasia } \\
\text { tabularis or acacia }\end{array}$ & & $18 / 431$ & \\
\hline 5 & Pomelo, lemon and ginger & & $1 / 431$ & \\
\hline 6 & Pomelo, persimmon and ginger & & $1 / 431$ & \\
\hline 7 & Longan, cassava and banana & & $1 / 431$ & \\
\hline \multirow[t]{2}{*}{8} & $\begin{array}{l}\text { Coffee-based systems } \\
\text { - Coffee with temperate and tropical fruit trees (one } \\
\text { fruit tree species or mix of fruit trees, including }\end{array}$ & \multirow{10}{*}{$\begin{array}{l}\text { Above } \\
800\end{array}$} & $83 / 538$ & $\begin{array}{l}\text { Chieng Bom, } \\
\text { Thuan Chau, } \\
\text { Son La }\end{array}$ \\
\hline & $\begin{array}{l}\text { plum, peach, son tra, black canarium, banana, } \\
\text { lemon, jack fruit, mango, longan, lychee (Litchi } \\
\text { chinensis), apricot, rambutan) } \\
\text { - Coffee in a mixed system with fruit and timber } \\
\text { trees (melia, Chukrasia tabularis A. Juss (lat), } \\
\text { Michelia mediocris Dandy, mắc khén } \\
\text { (Zanthoxylum rhetsa (Roxb.) DC), manglietia) } \\
\text { - Coffee in a mixed system with short-term crops } \\
\text { (ginger, cassava) and fruit and timber trees } \\
\text { - Coffee with Leucaena glauca }\end{array}$ & & $4 / 538$ & $\begin{array}{l}\text { Toa Tinh, } \\
\text { Tuan Giao, } \\
\text { Dien Bien }\end{array}$ \\
\hline 9 & Son tra intercropped with maize or upland rice & & $18 / 538$ & \multirow{3}{*}{$\begin{array}{l}\text { Co Ma, Thuan } \\
\text { Chau, Son La }\end{array}$} \\
\hline 10 & Persimmon, peach, longan, mango, Brassica juncea & & $1 / 538$ & \\
\hline 11 & Persimmon, peach, longan, mango, maize, cassava & & $1 / 538$ & \\
\hline 12 & Amomum under natural forest canopy & & $24 / 538$ & \multirow{4}{*}{$\begin{array}{l}\text { Toa Tinh, } \\
\text { Tuan Giao, } \\
\text { Dien Bien }\end{array}$} \\
\hline 13 & Amomum with son tra alone or with plum, peach & & $31 / 538$ & \\
\hline 14 & Amomum with son tra and pine & & $2 / 538$ & \\
\hline 15 & Cardamom under natural forest or son tra plantation & & $4 / 538$ & \\
\hline 16 & $\begin{array}{l}\text { Shan tea-based systems } \\
\text { - Shan tea intercropped with short-term crops } \\
\text { (upland rice, cassava, maize, y di (Coix Lacryma- } \\
\text { jobi L.)) } \\
\text { - Shan tea with cinnamon }\end{array}$ & & $\begin{array}{c}21 / 538 \\
1 / 538\end{array}$ & $\begin{array}{l}\text { Ban Cong, } \\
\text { Tram Tau, Yen } \\
\text { Bai }\end{array}$ \\
\hline
\end{tabular}

[Source: Survey data] 


\subsection{Economic effectiveness of some domi-} nant farming systems in the study villages

The average profits of upland farming systems varied by elevation and by region owing to differences in biophysical conditions, investments (in fertilizers, labour etc.). In general, returns were relatively low and often the total income just covered the financial investment. The estimated profits from the different farming systems are summarized in Table 2. The detailed estimated profits (USD $1=$ VND 20000 ) of the dominant cropping systems in each of the study villages are presented in Annex 2 Table A2.2.

The profit from maize cultivation varied from USD $45 \$$ at elevations above 800 masl to USD 600 ha/year at intermediate elevations. Cassava monoculture generated a comparatively low profit, from USD 147 to $287 \mathrm{ha} /$ year, however, it provided a good alternative to rice and maize as soil fertility declined. Although paddy and upland rice made minor contributions to household incomes (USD 45-250 ha/year), the harvest was indispensable for ensuring household food security. The systems with perennial species - for example, tea, coffee, son tra or intercropping showed significantly higher incomes compared to monocultural systems (USD 900-2300 ha/year), especially the systems with coffee planted in association with canarium and longan. The price of coffee fluctuated in the years of calculation, however, the price of canarium and longan remained stable keeping the system's profit high (USD 3000 and 10000 ha/year respectively)

\subsection{Tree-planting practices and preferred} tree species

More than two-thirds (71\%) of the interviewed farmers had trees on their farms for domestic use and income generation. Trees were planted mostly in homegardens or scattered around the farms, at the top or bottom of hills, or along the contours of slopes. The main challenges with managing trees that were mentioned by farmers were limited land resources (36\%), limited options for species with high market demand (38\%), lack of investment capital (17\%), and pests and diseases (17\%). Few farmers were familiar with the term agroforestry. Following a detailed explanation by the research team, $78 \%$ of the respondents reported they knew about the practice but few (10\%) practised any form of agroforestry on their farms.

All the interviewed farmers were well aware of the issues related to monocultural staple crops on slopes and were willing to plant more trees on their farms to reverse low soil fertility, increase soil protection and benefit from the long-term stability of tree-based systems. However, they were concerned about the availability of species of high economic benefit and the availability of markets. Species that the farmers preferred to plant on their farms are shown in Table 4.

Below 400 masl, farmers preferred eucalyptus and acacia because of their suitability to the natural conditions and strong local demand for timber. Of the fruit tree species, farmers preferred late-fruiting longan and orange for their marketability.

At 400-800 masl, farmers preferred eucalyptus and Canarium. Canarium is a multipurpose species with long rotation that 
Table 4. Species farmers preferred to plant, by elevation range

\begin{tabular}{|c|c|c|}
\hline Elevation & Species & Reason \\
\hline \multirow[t]{3}{*}{$<400 \mathrm{~m}$} & $\begin{array}{l}\text { Hybrid eucalyptus, } \\
\text { Acacia auriculiformis }\end{array}$ & $\begin{array}{l}\text { In Son La and Dien Bien, these species were in demand for house } \\
\text { construction because natural wood resources had been overexploited }\end{array}$ \\
\hline & Late-fruiting longan & This variety gives high fruit quality and a late harvesting season \\
\hline & Orange & Traditionally grown in Yen Bai with relative good market price \\
\hline \multirow[t]{4}{*}{$400-800 \mathrm{~m}$} & Coffee & $\begin{array}{l}\text { Can give high economic returns but required high investment for } \\
\text { establishment and annual inputs. Many farmers had successful coffee } \\
\text { plantations }\end{array}$ \\
\hline & Macadamia & High potential for income generation if able to enter international markets \\
\hline & Canarium nigrum & Multipurpose native species with high value nuts and timber \\
\hline & Eucalyptus & In demand for local use (house construction) \\
\hline \multirow{6}{*}{$>800 \mathrm{~m}$} & Son tra & $\begin{array}{l}\text { Native tree species, provided fruit for cash and home consumption, shade, } \\
\text { soil protection and timber. It can be intercropped with timber species or } \\
\text { crops. Good market opportunities }\end{array}$ \\
\hline & Shan tea & $\begin{array}{l}\text { Considered a good investment owing to long life }(100+\text { years), high yields } \\
\text { and good quality tea (well-developed market locally and for export to Yen } \\
\text { Bai) }\end{array}$ \\
\hline & Peach & Can be grown at high elevations on sloping land \\
\hline & Walnut & $\begin{array}{l}\text { Grows well at high elevations (Co Ma), high yields, good market } \\
\text { opportunities }\end{array}$ \\
\hline & $\begin{array}{l}\text { Cunminghamia } \\
\text { lanceolata Lamb ('sa } \\
\text { moc') }\end{array}$ & Timber for house construction, grows well at high elevations \\
\hline & $\begin{array}{l}\text { Amomum sp. } \\
\text { Cardamom }\end{array}$ & Planted under forest canopy, good market opportunities \\
\hline
\end{tabular}

provides nuts and, eventually, high-quality timber. Some farmers planted Canarium as a shade tree for coffee. Macadamia was a newly introduced species that grew well in the Northwest and produced good yields ( $4 \mathrm{~kg} /$ tree in the $8^{\text {th }}$ year) (Mai Son district) and had potential for export to international markets.

At high elevations, farmers preferred temperate timber and fruit/nut species, including son tra, peach or shan tea. Walnut had shown good growth in Thuan Chau above 1100 masl, and could be a promising option.

\subsection{General findings of the agroforestry adoption survey}

The results of the study showed that farmers practised agroforestry for a number of reasons. The primary reason for $79 \%$ of farmers ( $N=210$, multiple choice) was higher income and more effective land use; $28 \%$ practised agroforestry in order to provide shade for understory crops. Only $2 \%$ of respondents practised agroforestry for soil and water conservation (although farmers were aware of this benefit of tree cultivation) and $4 \%$ for more efficient fertilizer use. Thus, the majority of farmers primarily integrated trees on their farms to enhance income: $86 \%$ of respondents reported that their farming systems generated more income from the combined yields of tree and associated annual crops. Only a few respondents were not sure about the economic benefits of trees because they did not use the tree products or the benefits of trees were not clearly shown. A few respondents reported negative effects because of tree and crop competition. Most farmers learned agroforestry techniques 
from their neighbours and family members $(50 \%)$ or by themselves (46\%); only $4 \%$ of farmers learned agroforestry from TV or training.

Observations revealed that spatial arrangements of the agroforestry systems were not optimal. In some cases, tree spacing was too narrow or too wide or the distance between trees and crops too close, increasing competition for light, water and nutrients. Issues also arose in species' selection and site matching. Tropical fruit tree species - for example, jackfruit (Artocarpus heterophyllus), mango, longan, lychee (Litchi chinensis), rambutan (Nephelium lappaceum) were planted at elevations above 800 masl outside of their recommended range. Temperate fruit tree species are advisable for these altitudes.

\section{Discussion}

\subsection{Resilience, economic benefits and the} adoption potential of agroforestry systems

Overall, the most vulnerable areas in all three agro-ecological zones were the monocultural staple crops on steep slopes, particularly, where farmers applied large amounts of fertilizer to maize (at 400-800masl). These practices were strongly associated with soil erosion, soil degradation, water shortages, pests and diseases, loss of biodiversity and other environmental consequences. Other research has reported similar negative impacts on soil quality and soil loss (Ijaz et al. 2007; Nguyen 2007; Eludoyin and Wokocha 2011) and biodiversity and livelihoods' resilience (Horrigan et al. 2002) when cultivating steep slopes with annual crops. Cultiva- tion on steep slopes is prone to drought and flooding (Bennett et al. 2012).

Tea plantations, either with or without shade trees, were more resilient than monocultural staple crops. Integrating trees for shade over tea brought more economic benefits, diversified income, reduced soil erosion and increased biodiversity. Other tree-based systems - for example, fruit or timber trees with short-term crops or coffee with shade trees - provided the soil with more groundcover during the year, thus, reducing erosion and increasing carbon stock, water-holding capacity of the soil and biodiversity. Similar results have also been reported by Tang et al. (2002) and Schroth et al. (2004). Farms with trees in the study area had a shorter recovery time after natural disasters, except for cold spells, demonstrating economic and environmental resilience, as reported by Simelton et al. (2015).

With regards to market vulnerability, the systems with trees in association with other short-term crops and/or bushes diversified incomes of households, thus, reducing market risks. As informed by farmers, the prices of maize and cassava and even coffee had fluctuated significantly in the last few years, affecting their livelihoods. Tree products could compensate for the losses caused by price fluctuations, reducing vulnerability and risk.

In terms of system incomes, respondents reported that agroforestry systems brought higher incomes compared to monocultural practices. The systems with coffee and longan and coffee and canarium were good examples of the higher economic benefits of agroforestry (Table 2). This has been 
widely reported (Current and Scherr 1995; Craswell et al. 1997; Pye-Smith et al. 2008). The economic return of a farming system is one important criterion for farmers, especially poorer farmers, to adopt and maintain any farming technology (Scherr 1995; Dwivedi et al. 2007). The results of the study showed that the majority of farmers primarily integrated trees on their farms to enhance income (79\%). Similar results have also been reported by Bugayong and Carandang (2003) in the Philippines, where agroforestry had been promoted as a suitable land-use option. The long-term adoption of agroforestry in the northwestern region of Vietnam will depend on the economic benefits.

The study results also indicated that agroforestry has high adoption potential in the region because most of the respondents $(86 \%)$ reported greater income was associated with mixed tree and annual cropping compared to monocultures alone. This percentage could be higher if tree products were used for income generation, which would require more attention in species' selection, minimization of tree and annual crop competition through a sound system design, and improvement of farmers' marketing practices. Additional technical support in tree species' selection and system design could help farmers increase the benefits from their tree and crop systems.

Most farmers (95\%) learned agroforestry techniques from their neighbours or by themselves. This demonstrated that farmerto-farmer exchange was an effective way to disseminate new farming technologies. Similar results were also reported by Khaila et al. (2015) and Martini et al. (2016). The high percentage of farmers adopting agroforestry by themselves also indicated that they were unlikely to be fully aware of agroforestry options and would benefit from training.

\subsection{Potential agroforestry options for Northwestern Vietnam}

Given the issues related to monocultures of short-term crops on slopes, the advantages of tree-based system as discussed above, and that farmers are interested in tree-farming, agroforestry should be a priority land-use option and have great development potential in the northwestern region of Vietnam. Efforts in promoting agroforestry should focus, first, on improving existing agroforestry systems and gradually introducing new technologies and systems through a participatory approach. The improvement of the existing systems, as discussed above, could consist of species' selection and combinations, spatial arrangements of the components in the systems and system management. Moreover, agroforestry is a complex farming system that requires often higher and longer-term investment.

The benefits from agroforestry are usually reaped in the middle and long terms, hence, given the poverty of the farmers in the region, promotion of agroforestry should be accompanied by strong government support. Simelton et al. (2015) and Buttoud (FAO 2013) came to the same conclusion. Highquality grafted seedlings should be used to generate income sooner for farmers; grafted seedlings of canarium, longan and others commence fruit production in the third year or earlier compared to the sixth or seventh year when grown from seeds. Many of the 
species mentioned by respondents have been identified as priorities for Vietnam (Gunasena and Roshetko 2000). Further research on those species and related agroforestry systems is appropriate.

Agroforestry options for the region should be based on local contexts, including socio-economics, biophysics and market conditions (Coe et al. 2014). Farmers should have the option to adopt the whole, or part, of the recommended systems. Given the low income levels of farmers, agroforestry systems that combined trees and annual crops providing short-, middle- and long-term income have a high potential for adoption. Boundary planting and small woodlots in the agricultural landscape are also additional options for all elevations, which would provide additional income for farmers and in- crease landscape resilience (Manning et al. 2006, 2009; Dida et al, 2013; FAO 2014). Homegarden enrichment with fruit and multipurpose tree species and vegetables diversifies household food supplies and generates additional income. Building on the survey results, and including farmer's species preferences, the agroforestry systems in Table 5 are recommended.

\section{For elevations below 400 masl}

On the gentle slopes (below 15\%), intercropping fruit trees (for example, longan, mango, orange and guava) with short-term crops (for example, maize, ginger, beans, peanut) or fodder grasses could be a suitable option. Guava is recommended for association with orange to reduce citrus greening disease (VAAS 2012; Nguyen

Table 5: Potential agroforestry systems for Northwestern Vietnam

\begin{tabular}{|c|c|c|}
\hline $\begin{array}{l}\text { Elevation } \\
(\text { masl })\end{array}$ & Slope & Suggested agroforestry systems \\
\hline \multirow{4}{*}{$\begin{array}{l}\text { Below } \\
400\end{array}$} & \multirow{2}{*}{ Flat to gentle } & $\begin{array}{l}\text { Fruit species (for example, longan, mango, orange, guava) intercropped } \\
\text { with short-term crops or fodder grasses }\end{array}$ \\
\hline & & Bush tea with fruit and/or timber trees for shade \\
\hline & \multirow{2}{*}{ Steeper than $15^{\circ}$} & $\begin{array}{l}\text { Taungya systems with timber species (acacia, melia, Indian mahogany), } \\
\text { eucalyptus hybrid and manglietia with short-term crops and vegetative } \\
\text { strips }\end{array}$ \\
\hline & & $\begin{array}{l}\text { Timber species with bush tea or short-term crops or fodder grasses for } \\
\text { livestock in taungya system }\end{array}$ \\
\hline \multirow{4}{*}{$400-800$} & \multirow[t]{2}{*}{ Flat to gentle } & $\begin{array}{l}\text { Coffee-based agroforestry systems with fruit, multipurpose and/or } \\
\text { timber species }\end{array}$ \\
\hline & & Fruit or timber trees and short-term annual crops or medicinal plants \\
\hline & \multirow[t]{2}{*}{ Steep } & $\begin{array}{l}\text { Taungya system with timber trees, fodder or natural vegetative strips and } \\
\text { common short-term crops }\end{array}$ \\
\hline & & Timber trees with fodder grass for livestock \\
\hline \multirow{2}{*}{$\begin{array}{l}\text { Above } \\
800\end{array}$} & \multirow[b]{2}{*}{ Flat to gentle } & $\begin{array}{l}\text { Coffee-based agroforestry system with Coffea arabica and temperate } \\
\text { fruit (for example, son tra, plum, peach, and persimmon), walnut or }\end{array}$ \\
\hline & & $\begin{array}{l}\text { Temperate fruit, nut species, multipurpose tree species with temperate } \\
\text { vegetables and/or with short-term crops and/or fodder grass and/or } \\
\text { medicinal plants }\end{array}$ \\
\hline \multirow{2}{*}{$>800$} & \multirow{2}{*}{ Steep } & Temperate fruit, nut species, multipurpose tree species with cardamom \\
\hline & & Temperate fruit, nut species, multipurpose tree species with fodder grass \\
\hline
\end{tabular}


2013; Onagbola et al. 2010). Different fruit or timber trees could also be integrated into bush-tea plantations to provide shade and generate additional income. The specific spatial or temporal arrangements of the components within the systems should be designed based on the farmer's species' preferences, permanent agroforestry system or taungya system.

Owing to the intensive management schedules of fruit trees, timber trees are better options for steep slopes where access to remove harvested timber is possible. On slopes steeper than $15^{\circ}$, the integration of fast-growing timber species (such as acacia, melia, Indian mahogany, eucalyptus hybrid and manglietia) with natural vegetative strips as recommended by Stark et al. (2000) and short-term crops, bush tea or fodder grass alone in a taungya system would form terraces and control soil erosion. These systems are suitable for Yen Bai province where tea is the most important cash crop and markets are present for fast-growing timber as raw material for plywood, pulp and MDF.

\section{For elevations 400-800 masl}

Coffee is already a common and prioritized species in Son La and Dien Bien. These systems could be made more resilient and profitable through diversification with fruit, multipurpose or timber species. Market analysis would help farmers make better-informed decisions regarding if, and how, to diversify their coffee-based systems. Coffee requires water availability and intensive tending, thus, flat areas or those with gentle slopes are more appropriate for these systems. For areas where coffee is not an option, systems with fruit or timber trees and short-term annual crops or medicinal plants are possible options. On steep slopes, a hedgerow system with timber trees and fodder or natural vegetative strips and common short-term crops in a taungya system is recommended. The optimal spatial or temporal arrangements of the components in the systems should be designed based on the selected species to ensure minimal competition and maximum complementary effects.

\section{For elevations above 800 masl}

This agro-ecological zone is characterized by a temperate climate that is suitable for the growth of temperate crops and tree species. Agroforestry systems with temperate fruit or multipurpose tree species, shortterm crops and temperate vegetables could be suitable. Temperate fruits and vegetables and Coffea arabica would have market strength. Coffee-based agroforestry systems with temperate fruit (son tra, plum, peach and persimmon), walnut or timber trees (Cunninghamia lanceolata Lamb, pine) for shade are relevant options for areas with suitable slopes and soil conditions. In some villages in the study areas, such as Nhop in Son La and Hua Sa in Tuan Giao, Dien Bien, many farmers planted Coffea arabica in association with other tree species. Coffee showed good growth, however, improvement in the spatial arrangements of the components in these systems and in selection of associated species is recommended.

Furthermore, agroforestry systems with temperate fruit species and temperate vegetables and/or with short-term crops or fodder grass could be established in ar- 
eas with water availability. The production of temperate vegetables during summer or vegetable off-seasons would have market advantages. On steep slopes, a system with timber trees (such as pine) or multipurpose species (such as son tra) in association with amomum, cardamom or fodder grass could also be effective. Agroforestry with fodder grass and cattle components is a good option for farmers with a wider range of farming techniques and entrepreneurial skills.

\section{Conclusion}

Given the prevailing hilly landscape in the region with predominantly monocultural annual crops that lead to severe soil erosion, land degradation and low incomes, agroforestry should be the most suitable land-use option and thus has great development potential. Strengthening farmers' knowledge and understanding of agroforestry is an important priority. That could be achieved while improving existing agroforestry systems and gradually introducing new technologies and systems through a participatory research and technology development approach.

The improvement of the existing systems should include species' selection, access to quality germplasm, system design and training in system management. Agroforestry requires often higher and longerterm investment than annual crops but the farmers in the region have low income levels restricting their ability to invest. Promotion of agroforestry should therefore be accompanied by strong support from government. A clear plan to promote agroforestry should be developed by the Ministry of Agriculture and Rural Development in conjunction with agroforestry research and development organizations.

Agroforestry options for the region should be based on local contexts, including socio-economics, biophysics and market conditions. Agroforestry systems that combined trees and annual crops that provided short-, middle- and long-term income have high potential for adoption. Boundary planting and small woodlots in agricultural landscapes are also additional options for all elevations that would provide additional income for farmers and increase landscape resilience. Homegarden enrichment with fruit and multipurpose tree species and vegetables diversifies household food supplies and generates additional income.

\section{Acknowledgement}

The study was a part of the Agroforestry for Livelihoods of Smallholder Farmers in Northwestern Vietnam project, funded by the Australian Centre for International Agricultural Research and the CGIAR Research Program on Forests, Trees and Agroforestry. The project had the goal of improving the performance of smallholders' farming systems through agroforestry while conserving a healthy environment for future generations.

\section{References}

Bennett A, Bending G, Chandler D, Hilton S, Mills P (2012) Meeting the demand for crop production: the challenge of yield decline in crops grown in short rotations. Biol Rev Camb Philos Soc. 2012 Feb:87(1): 52-71. DOI: 10.1111/j.1469-185X.2011.00184.x.

Blanco-Canqui H, Lal R (2008) Principles 
of soil conservation and management. Springer. pp. 261-283.

Brenda BL (2010) The role of agroforestry in reducing water loss through soil evaporation and crop transpiration in coffee agroecosystems. Agricultural and Forest Meteorology 150 (2010): 510-518.

Bugayong LA, Carandang WM (2003) Agroforestry practices in a community-based forest management site. XII World Forestry Congress, Quebec City, Canada. http://www.fao.org/docrep/ ARTICLE/WFC/XII/0447-B5.HTM.

CEM Vietnam [Centre For Environmental Monitoring] (2016) Đa dang sinh hoc. Biodiversity. Vietnam Environment Administration, Hanoi. http://cem. gov.vn/Portals/0/2016/TinBai/Chuong\%207.pdf.

Charles RL, Munishi PKT, Nzunda EF (2013) Agroforestry as adaptation strategy under climate change in Mwanga District, Kilimanjaro, Tanzania. Int $J$ Environ Protect 3(11): 29-38.

Chaudhury M (2009) Assessing the protection of forest-based environmental services in the GMS. Working Paper no. APFSOS II/WP/2009/14. Asia-pacific Forestry Sector Outlook Study II. Food and Agriculture Organization of the United Nations, Rome, Italy.

Coe R, Sinclair F, Barrios E (2014) Scaling up agroforestry requires research 'in' rather than 'for' development. Cur Opin Env Sus 6(February): 73-77.

Current D, Scherr S (1995) Farmer costs and benefits from agroforestry and farm forestry projects in Central America and the Caribbean: implications for policy. Agrofor Sys 30: 87-103

Dawson IK, Place F, Torquebiau El, Malézieux E, Iiyama M, Sileshi WG, Kehlenbeck K, Masters E, McMullin S, Jamnadass R (2013) Agroforestry, food and nutritional security. Background paper for the International Conference on Forests for Food Security and Nutrition, FAO, Rome, 3-15 May, 2013. http://www.fao.org/ forestry/37082-4957fe26afbc90d1e9c 0356c48185295.pdf

Dida J, Paquit J, Magnaye G, Boongaling C, Bantayan N (2013) Assessment of Trees Outside Forest (TOF) in Selected Makiling Subwatersheds. International Journal of Agriculture System. Volume 1, Issue 2, December 2013.

DONRE Son La (2014) Biến đổi khi hậu tại Son La, hiện trạng và hành động úng phó. Climate change in Son La: current situation and adaptation action. Department of Natural Resources and Environment, Son La City, Son La Province, Vietnam. http://sotnmt.sonla.gov. vn/NewsDetail.aspx?id=43.

Dwivedi RP, Kareemulla K, Singh R, Rizvi RH, Chauhan J (2007) Socio-economic analysis of agroforestry systems in Western Uttar Pradesh. Indian Res. J. Ext. Edu 7: 18-22.

Eludoyin OS, Wokocha CC (2011) Soil dynamics under continuous monocropping of maize (Zea mays) on a Forest Alfisol in South-Western Nigeria. Asian J Agric Sci 3(2): 58-62.

FAO (2013). Advancing Agroforestry on the Policy Agenda: A guide for decision- 
makers. Buttoud G. with Ajayi O, Detlefsen G, Place F, Torquebiau E. Agroforestry Working Paper no. 1. Food and Agriculture Organization of the United Nations. FAO, Rome.

FAO (2014) Assessing and promoting trees outside forests (TOF) in Asian rice production landscapes. Asia Regional Rice Initiative: Biodiversity, Landscapes \& Ecosystem Services in Rice Production Systems. FAO, Rome. http://www.fao.org/3/a-i4161e.pdf.

Government of Vietnam (2007) Quyết dịnh 18/2007/QĐ-TTg phê duyệt Chiến luợc phát triển lâm nghiệp Việt Nam giai đoạn 2006-2020. Decision no. 18/2007/QD-TTg approving the Vietnam Forestry Development Strategy 2006-2020. Vietnam Administration of Forestry, Government of Vietnam, Hanoi, Vietnam. http://thuvienphapluat.vn/archive/Quyet-dinh/DecisionNo-18-2007-QD-TTg-of-February05-2007-approving-Vietnam-s-forestry-development-strategy-in-the2006-2020-period-vb75644t17.aspx

Gunasena HPM, Roshetko JM (2000) Tree Domestication in Southeast Asia: Results of a Regional Study on Institutional Capacity. International Centre for Research in Agroforestry, Bogor, Indonesia.

Hasan MK, Ashraful AKM (2006) Land degradation situation in Bangladesh and role of agroforestry. J Agric Rural Dev 4(1\&2).

Horrigan L, Lawrence RS, Walker P (2002) How sustainable agriculture can address the environmental and human health harms of industrial agriculture. Env Heal Persp 110(5). Retrieved August 23, 2012.

Ijaz A, Khan F, Bhatti AU (2007) Soil and nutrient losses by water erosion under mono-cropping and legume intercropping on sloping land. Pakistan J Agric Res 20(3-4).

IPCN Vietnam (2016) Tổng quan về Điện Biên. Overview of Dien Bien. Investment Promotion Center North Vietnam, Ministry of Planning and Investment, Hanoi, Vietnam. http:// ipcn.mpi.gov.vn/Home/NewsDetail. aspx?CatId $=41 \& \mathrm{id}=388$

Jama B, Kwesiga F, Niang A (2006) Agroforestry innovations for soil fertility management in sub-Saharan Africa: prospects and challenges ahead. In: Garrity P, ed. World Agroforestry Into the Future. World Agroforestry Centre, Nairobi. http://www.worldagroforestry.org/downloads/publications/pdfs/ bc06144.pdf.

Jamnadass R, Place F, Torquebiau E, Malézieux E, Iiyama M, Sileshi GW, Kehlenbeck K, Masters E, McMullin S, Weber JC, Dawson IK (2013) Agroforestry, food and nutritional security. Working Paper No. 170. World Agroforestry Centre, Nairobi, Kenya. http:// dx.doi.org/10.5716/WP13054.PDF.

Kaczan D, Arslan A, Lipper L (2013) Climate-smart agriculture? A review of current practice of agroforestry and conservation agriculture in Malawi and Zambia. ESA Working Paper no. 13-0, October 2013. Agricultural Development Economics Division, FAO, 
Rome.

Khaila S, Tchuwa F, Franzel S, Simpson S (2015) The farmer-to-farmer extension approach in Malawi: a survey of lead farmers. Working Paper no. 189. World Agroforestry Centre, Nairobi, Kenya. http://dx.doi.org/10.5716/WP14200. PDF.

Khanh Tinh Cong (2012) Project report on "Điều tra, đánh giá thực trạng đời sống đồng bào dân tộc thiểu số cu trú ơ vùng cao núi đá, nơi thường xuyên xảy ra thiên tai (Assessment of current living conditions of ethnic minorities in the mountainous areas where natural disasters happen frequently), ethnic policy department, Ethnic Committee of Vietnam. Assess on 5.05.2015, http://ambn.vn/product/13338/ di $\%$ E $1 \%$ BB $\% 81 u$-tra-danh-gia-thuctrang-doi-song-d $\% \mathrm{C} 3 \% \mathrm{~B} 4 \mathrm{ng}$-baodan-toc-thieu-so-nam-2012.html

La N, Do VH, Pham HT, Agustin M, Do TL, Hoang TL et al. (2016) Participatory Farmer Trials Results. Technical report no. 19. Agroforestry for Livelihood of Smallholder farmers in Northwest Viet Nam project. World Agroforestry Centre, Hanoi, Viet Nam. pp. 35-38

Lasco DR, Delfino RP, Espaldon MLO (2014) Agroforestry systems: helping smallholders adapt to climate risks while mitigating climate change. WIREs: Climate Change 5(6): 825833. DOI: 10.1002/wcc.301.

Long Vu (2009) Về quyền sủ dụng đất làm nuoong rẫy của đồng bào dân tộc thiểu số ở miền núi. Land-use rights for upland farming of mountainous ethnic groups in Vietnam. Vietnamese Academy of Forest Sciences, Hanoi, Viet Nam. http://vafs.gov.vn/vn/2009/03/ ve-quyen-su-dung-dat-lam-nuongray-cua-dong-bao-dan-toc-thieu-so-omien-nui/.

Manning, AD, Gibbons P, Lindenmayer DB (2009) Scattered trees: a complementary strategy for facilitating adaptive responses to climate change in modified landscapes? J App Ecol 46: 915-919. DOI: 10.1111/j.13652664.2009.01657.

Manning AD, Fischer J, Lindenmayer DB (2006) Scattered trees are keystone structures: implications for conservation. Biol Conserv 132(3): 311-321.

Martini E, Roshetko JM, Paramita E (2016) Can farmer-to-farmer communication boost the dissemination of agroforestry innovations? A case study in Sulawesi, Indonesia. Agroforestry Systems 90: 1-25. DOI: 10.1007/s10457-0160011-3.

Mbow C, Noordwijk MV, Luedeling E, Neufeldt H, Minang PA, Kowero G (2014) Agroforestry solutions to address food security and climate change challenges in Africa. Cur Opin Env Sus 6 (February): 61-67.

Murthy IK, Gupta M, Tomar S, Munsi M, Tiwari R, Hegde GT, Ravindranath NH (2013) Carbon sequestration potential of agroforestry systems in India. $J$ Earth Sci Climate Change 4-1: 131. DOI:10.4172/2157-7617.1000131.

Nair PKR (1993) An introduction to agroforestry. Springer Science \& Business Media 
Nguyen K (2014) Mô hình trồng ổi xen cam để hạn chế bệnh greening. System of guava intercropped with oranges for combating greening disease. Vietnam Agriculture. http://nongnghiep. vn/trong-oi-xen-cam-han-che-benhgreening-post119913.html. Accessed 09.01.2014.

Nguyen VD, Douglas J, Momorrow J, Lindley S, Dao K, Nguyen TB, Tran TV, Le HT, Nguyen T (2007) Erosion and nutrient loss on sloping land under intense cultivation in Southern Vietnam. Geog Res 46(1): 4-16 DOI: 10.1111/ j.1745-5871.2007.00487.

Onagbola EO, Rouseff RL, Smoot JM, Stelinski LL (2010) Guava leaf volatiles and dimethyl disulphide inhibit response of Diaphorina citri Kuwayama to host plant volatiles. J App Ent 135(6): 404-414.

Pattanayak S, Mercer DE (1996) Valuing soil conservation benefits of agroforestry practices. FPEI Working Paper no. 59. Southeastern Center for Forest Economics Research, Research Triangle Park, NC, USA. https://www.srs. fs.usda.gov/econ/pubs/fpei/fpei59.pdf. Pham TTH, Turner S, Trincsi K (2015) Applying a systematic review to land use land cover change in Northern Upland Vietnam: the missing case of the borderlands. Geog Res 53(4): 419-435. DOI: $10.1111 / 1745-5871.12133$.

Pinho RC, Miller RP, Alfaia S (2012) Agroforestry and the improvement of soil fertility: a view from Amazonia. App Env Soil Sci 2012, article ID 616383. http:// dx.doi.org/10.1155/2012/616383.
Pye-Smith C, Hailu M, Selvarajah-Jaffery R, Vanhoutte K (2008) Agroforestry for food security and healthy ecosystems. World Agroforestry Centre Annual Report 2007-2008. World Agroforestry Centre (ICRAF), Nairobi, Kenya.

Rao KPC, Verchot LV, Laarman J (2007) Adaptation to climate change through sustainable management and development of agroforestry systems. SAT e-Journal 4(1). https://www.researchgate.net/publication/237826845 Adaptation to Climate Change through Sustainable Management and Development of_Agroforestry_Systems.

Roshetko JM, Lasco RD, Delos Angeles MD (2007) Smallholder agroforestry systems for carbon storage. Mit Adap Strat Glo Chan 12(2): 219-242.

Roshetko JM, Rohadi D, Perdana A, Sabastian G, Nuryartono N, Pramono AA, Widyani N, Manalu P, Fauzi MA, Sumardamto P, Kusumowardhani N (2013) Teak agroforestry systems for livelihood enhancement, industrial timber production, and environmental rehabilitation. For Tree Liv 22(4): 241-256 DOI: 10.1080/14728028.2013.855150. Scherr SJ (1995) Economic factors in farmer adoption of agroforestry: patterns observed in Western Kenya. Wor Dev 23(5): 787-804.

Schroth G, Fonseca GAB, Harvey CA, Gascon C, Vasconcelos H, Izac AM (2004) Agroforestry and biodiversity conservation in tropical landscapes. Island Press, Washington DC, USA. http:// library.uniteddiversity.coop/Permaculture/Agroforestry/Agroforestry_and 
Biodiversity_Conservation in Tropical_Landscapes.pdf.

Simelton E, Catacutan, DC, Dao CT, Le DT (2015a) Agroforestry: a policy imperative for Vietnam. Policy brief no. 1. World Agroforestry Centre (ICRAF), Hanoi, Viet Nam. http://www.worldagroforestry.org/region/sea/publications/ detail?pubID=3362.

Simelton E, Dam VB, Catacutan D (2015b) Trees and agroforestry for coping with extreme weather events: experiences from northern and central Viet Nam. Agrofor Sys. DOI 10.1007/s10457015-9835-5.

Stark M, Garrity DP, Mercado A, Jutzi SC (2000) Building research on farmers' innovations: low-cost natural vegetative strips and soil fertility management. Paper presented at the Environmental Education Network of the Philippines conference, Misamis Oriental State College of Agriculture, Claveria, 31 May-1 June 2000.

Stibig HJ, Stolle F, Dennis R, Feldkötter C (2007) Forest cover change in Southeast Asia: the regional pattern. Joint Research Centre, European Commission, Brussels, Belgium. http://publications.jrc.ec.europa.eu/repository/ bitstream/111111111/477/1/eur\%20 $22896 \% 20$ forest $\% 20$ change $\% 20$ pattern $\% 20$ se-asia.pdf.
Tang Y, Sun H, Xie J, Chen J (2002) Soil conservation and sustainable management of sloping agricultural lands in China. 12th ISCO Conference, Beijing 2002. Chengdu Institute of Biology, Chinese Academy of Sciences, Chengdu, People's Republic of China. http:// www.tucson.ars.ag.gov/isco/isco12/ VolumeIII/SoilConservationandSustainable.pdf.

VAAS (2012) Áp dụng TBKT trồng cam sành. Applying advanced science and technology in orange cultivation. Vietnam Academy of Agricultural Science, Hanoi, Viet Nam. http://www.vaas. org.vn/ap-dung-tbkt-trong-cam-sanha6131.html. Accessed 07/12/2012.

Verchot LV, van Noordwijk M, Kandji S. et al. Mitig Adapt Strat Glob Change (2007) 12: 901. DOI:10.1007/s11027007-9105-6

VNFOREST (2008) Rùng là nguồn tài nguyên quý giá của đất nước ta. Forest is a precious resource of our country. Vietnam Administration of Forestry, Government of Viet Nam. http://tongcuclamnghiep.gov.vn/tintuc/6/a-159/48.html.

Young A (2002) Effects of trees on soils. Special Supplement on Agroforestry. The Natural Farmer. Spring. http:// www.nofa.org/tnf/sp02/supplement/ effects.pdf. 